Wilfrid Laurier University

Scholars Commons @ Laurier

Political Science Faculty Publications

Political Science

$9-1-1987$

\title{
Liberalism, Human Rights, and Human Dignity
}

Neil Mitchell

University of New Mexico

Rhoda E. Howard-Hassmann

Wilfrid Laurier University, hassmann@wlu.ca

Jack Donnelly

University of North Carolina Chapel Hill

Follow this and additional works at: https://scholars.wlu.ca/poli_faculty

\section{Recommended Citation}

Mitchell, Neil; Howard-Hassmann, Rhoda E.; and Donnelly, Jack, "Liberalism, Human Rights, and Human Dignity" (1987). Political Science Faculty Publications. 20.

https://scholars.wlu.ca/poli_faculty/20

This Article is brought to you for free and open access by the Political Science at Scholars Commons @ Laurier. It has been accepted for inclusion in Political Science Faculty Publications by an authorized administrator of Scholars Commons@ Laurier. For more information, please contact scholarscommons@wlu.ca. 


\section{LIBERALISM, HUMAN RIGHTS, AND HUMAN DIGNITY}

Do international standards regarding human rights require the existence of a liberal regime? This was the thrust of Rhoda Howard and Jack Donnelly's essay in the September 1986 issue of this Review. Neil Mitchell takes vigorous issue with this contention, arguing first and foremost that Howard and Donnelly have not defined liberalism satisfactorily. Howard and Donnelly present a spirited rejoinder.

\section{In "Human Dignity,} Human Rights, and Political Regimes" (this Review, September 1986), Rhoda Howard and Jack Donnelly argue that human rights require liberalism: "We contend that internationally recognized human rights require a liberal regime" (p. 802 ). This contention is supported by a very abstract definition of liberalism, by inappropriate comparisons, by neglecting other ideological traditions that can also claim to support human rights and the integrity of individuals, and by ignoring consideration of other conditions that may be necessary for human rights.

Howard and Donnelly's definition of liberalism is tied to no particular theorist, century, or country, making it easier to produce a set of values with an article-byarticle correspondence to the Universal Declaration of Human Rights. The definition is variously defended as an "ideal type," as "a plausible standard reading of the liberal tradition," and finally with the revealing comment, "Our subject in this article is human rights, not liberalism" (p. 802). Their subject needs be both if they are to make their argument effectively. Simply stipulating a set of values and calling them liberalism and then showing that these values are compatible with a conception of human rights is not a compelling method of argument. One could as easily stipulate a floating pastiche of "socialist" values, affiliated neither with Marx nor with Tawney, grounded on no particular piece of history or society, but which also fits human rights. Without a more careful explication of liberalism, the connection Howard and Donnelly assert raises all sorts of objections. What we end up with is a philosophical hybrid that no one will claim but that is apparently created by crossing John Locke with Edward Kennedy, perhaps in the cosy confines of a British welfare state that works, presumably after having first detached Northern Ireland.

Thus, we have emphasis on the prepolitical rights of individuals that one finds in the Two Treatises, without the more awkward bits like the limiting of government to the protection of property. Instead we are told that liberalism means that government is required "to cancel unjustifiable market inequalities" and ensure a decent standard of life for all-so bringing it into line with Articles 22 and 25 of the universal declaration. The familiar liberal theme, going back to Locke's peculiar "title" to charity, and often espoused by Thatcher or Reagan, that these needs can be met privately is not considered by our authors. They even extend their argument to include a right to work (Article 23) - not simply the more recognizable liberal position of a chance to work-which they derive from the

\section{AMERICAN POLITICAL SCIENCE REVIEW VOL. 81 NO. 3 SEPTEMBER 1987}




\section{American Political Science Review Vol. 81}

liberal principle of "equal concern and respect." One wonders why they stop here-why not also derive equality of condition from this principle? They do say that "a certain amount of economic liberty is also required" to "reflect free decisions based on personal values that arise from autonomously chosen conceptions of the good life" (p. 803), so rather than derive absolute equality, perhaps we should stop at the well-known liberal slogan "to each according to his need"!

This argument that liberalism is not only fully consonant with civil and political rights but also with economic and social rights crystallizes in the contrast made between liberalism and the minimal state. The minimal state which elsewhere one sometimes hears described as "classical liberalism," is for Howard and Donnelly not liberalism because "in its very essence [it] is a violator of human rights" (p. 807). But their argument does not rest on circularity alone; the authors add to this their uncertainty as to whether minimalism is logically consistent: "Beyond minimalism's obvious incompatibility with international human rights standards . . . its deep commitment to protecting private property while denying all other economic and social rights borders on logical contradiction" (p. 807). While hedging with the word "borders," Howard and Donnelly say that unlimited accumulation (which one finds in the scholarly interpretation of the Two Treatises incidentally) cannot be justified in terms of "enjoyment of personal autonomy" (p. 807). For "at a certain point, additional economic resources contribute nothing at all to personal autonomy" (p. 807). Who is to determine this point without infringing on the other liberal principle that they assert of "one citizen's conception of the good life being no nobler or superior to another's" (p. 803) is not made clear, and the other grounds for unlimited accumulation-found in Locke, for example-are not considered. Further, it is argued that the minimal state is "selfdestructing if it recognizes equal, universal civil and political rights" (p. 807). People will use their political rights to destroy minimalism and institute welfare states. But, of course, there is no general requirement that I am aware of that value systems, traditions, or regimes be internally consistent; they may even contain within them the "seeds of their own destruction." Howard and Donnelly hold the conviction that Sir Isaiah Berlin warns against in "Two Concepts of Liberty," namely, "that all the positive values in which men have believed must, in the end, be compatible, and perhaps even entail one another" $(1970,167)$. In any case the ideal of a minimal state is electorally popular at the moment, as the elections and reelections of Thatcher and Reagan illustrate. The point is that the minimal state is not compatible with some articles of the universal declaration, as Howard and Donnelly recognize, but their claim, which is presumably essential to their thesis, that it is somehow a less "pure" form of liberalism is not convincing, given the arguments presented. Without clearly specifying the origins of liberalism, then, one is left with the suspicion that the method of constructing the "plausible standard reading of the liberal tradition" is to first read the universal declaration and then pick, choose, derive, and discard as necessary.

The authors contrast liberalism with what they call communitarian regimes "that give ideological and practical priority to the community ... over the individual" (p. 808). One type of communitarian regime is communism. Their abstract, or "pure," definition of liberalism is inappropriately compared to a concept of communism based on "the structure and official ideology of contemporary communist societies" (p. 809). Not surprisingly, communism is found to fall short of human-rights standards-as would liberalism if it was constituted in a 


\section{Liberalism and Human Rights}

similar way by, say, the McCarranWalter Act, the Diplock courts of Northern Ireland, and so on.

In communist societies, we are told, "one is equal not by birth or by nature, but only to the extent that one is essentially indistinguishable from one's fellow communist citizens" (p. 810). Communism, then for Howard and Donnelly, is Orwell's satire or "the dark night of totalitarianism in which all cats are grey." They go on to claim that communism is even incompatible with economic and social rights because these rights are "contingent on the discharge of social duties" (p. 810). This argument seems to forget that civil and political rights, even in liberal theory (let alone practice), are contingent. With John Stuart Mill, freedom of opinion is contingent on not harming others or not instigating "some mischievous act"-corn dealers starve the poor. With John Locke, toleration is contingent on loyalty (not to be extended to Catholics, for example, in his day). And in practice, of course, foreign "communists" are denied entry to the United States, and domestic communists are off and on denied free speech for national-security reasons. In short, the good of the community in liberalism also takes precedence over individual rights. What makes Howard and Donnelly's argument here extraordinary is that the penultimate article of the Universal Declaration of Human Rights, which they say they "accept without argument," explicitly recognizes the importance of "discharging social duties" and the contingency of individual rights on these duties, despite their claim to the contrary (p. 806).

Now to move from what is included to what is omitted; Howard and Donnelly, in asserting that human rights require a particular type of liberal regime, ignore other traditions and value systems that condemn torture and political repression and provide for economic and social security. Most obvious, of course, is
Marxism, not as caricatured in the Soviet constitution or Soviet practice but that form of Marxism that provides the analysis of the Paris Commune or looks forward to "an association, in which the free development of each is the condition for the free development of all." We could also look at the socialism of R. H. Tawney, George Orwell, Bernard Crick, or the Swedish Social Democrats for that matter. Liberalism, then, even when it is defined as it is in this article, does not have exclusive claim to values that support human rights. There are alternative traditions and regimes, and thus liberalism cannot be said to be a "requirement" for human rights.

Finally, one is left puzzled by the wider purpose or use of the argument of Howard and Donnelly. It is remarkably barren in terms of producing empirical expectations about the variation in human-rights violations cross-nationally, except for the unexciting proposition that liberal societies will do better than other societies of the world, which, right-wing or left-wing, communist or corporatist, presumably do more or less equally badly. At least with Jeane Kirkpatrick, whose work develops some similar themes, we are provided with distinctions in terms of human rights performance in "nondemocratic" countries that are empirically testable. And while the comparatively good performance-though only in terms of civil and political rights-of liberal regimes is plausibly attributed to values, no consideration is given to alternative explanations or other conditions, like the presence of a market economy or the generally superior material well-being that one also finds in these societies. Nor is any explanation provided for why human-rights violations still occur within these societies. ${ }^{1}$ Is it the result of the inadequate diffusion of liberal values? But we are never even told who should hold these values: the people, policymakers, or both. Nor are we told why these societies, 


\section{American Political Science Review Vol. 81}

in their foreign policies, can consistently support hideous client regimes if there is such a "deep and essential theoretical connection" between human rights and liberalism. Whatever the article's purpose, the reason for this comment is the worry that in such an important and politically sensitive area this article, perhaps inadvertently, contributes to what our profession should be dedicated to fight-ethnocentrism.

\section{NeIL MitChell}

\section{University of New Mexico}

Neil Mitchell's major concern appears to be our definition of liberalism, particularly that a liberal regime in our conception looks like a European welfare state rather than the world of Locke, or the robber barons, or the United States in 1987. This results, he claims, from the fact that it is "tied to no particular theorist, century, or country." Even more seriously, he charges that it "is a philosophical hybrid that no one will claim" and that his "suspicion" is that our procedure was "to first read the universal declaration and then pick, choose, derive, and discard as necessary."

In "Human Dignity, Human Rights, and Political Regimes," we directly and explicitly (pp. 802-3) tie our conception of liberalism to the work of Ronald Dworkin, which stands firmly within a well-recognized theoretical tradition running back to Locke, through Paine. The implicit empirical referent for our ideal type is the modern liberal-democratic welfare state, particularly in its European social-democratic form. We connect the socialism of Tawney, Orwell, Crick, and the Swedish Social Democrats with liberal social democracy. In other words, we explicitly argue for both the theoretical cogency and historical pedigree of our conception of liberalism.

Of course, liberalism thus ends up look- ing more like a world of "to each according to his need" than Engels's account of early industrial Manchester. This has been precisely the direction of development of the liberal tradition, both in theory and in practice, over the last century. Our ideal type was intended to fit this real and concretely embodied tradition, rather than to maintain an anachronistic fidelity to Locke, as Mitchell would apparently have us do. We see no reason why liberals must accept every opinion of Locke-for example, nontoleration of Catholics-as dogma. Locke was certainly an important source of the liberal tradition, but he did not engrave the complete tenets of liberalism in stone. We can see no reason why liberals should be required to wear the cement boots of a three-hundred-year-old book of 243 numbered paragraphs. Mitchell's reference to Mill, moreover, seems a non sequitur; we can recall no defense of natural or human rights in any of Mill's major political or moral works.

It is true that we provided a country referent for communist states, namely Soviet-bloc countries, but not for liberal. We agree that we ought to have provided such a referent, as Mitchell appears, especially in his statement that "these [liberal] societies in their foreign policies can consistently support hideous client regimes," to think that our implicit referent is the United States. It is not. We are perfectly prepared to entertain the hypothesis that the United States more closely approximates a minimal than a liberal state (and not merely because minimalism is currently "electorally popular" under Reagan). A society that has the material capacity to provide universal health care or universal maternal benefits but nevertheless chooses not to does not strike us as one based on equal concern and respect for all its citizens (see Goldstein, N.d.). The U.S. government's lack of respect for its citizens can perhaps explain why it supports hideous client 


\section{Liberalism and Human Rights}

regimes such as Chile and Guatemala, whereas Norway, for example, extends its foreign aid to such countries as Mozambique and Nicaragua (Skalnes and Egeland 1986).

Thus, we proposed an ideal type of rights-protecting regime, which resembles European social democracy and which we called liberalism. But suppose we are wrong and this regime should not be called liberal. Let's call it $x$ instead. Our argument remains the same: international human-rights standards require an $x$ regime.

Mitchell professes to be "puzzled by the wider purpose or use of this article." This is perhaps because he entirely misses its major, and quite explicit, analytical purpose, namely, to distinguish between societies based on human rights and societies with alternative-non-rightsbased-conceptions of human dignity. We do not argue that the only valuable way to preserve human dignity is through human rights; we merely argue that it is one way, and a particularly useful one in a world of state societies (p. 803). Mitchell could have challenged our definition of human rights as "entitlements that ground particularly powerful claims against the state, that each person has simply as a human being" (p. 802). Had he rejected our definition of rights and proposed another, he might have been able to show that $x$ is not the only rights-protecting regime and substantiated his claim that there are "alternative traditions and regimes" that support human rights. But as he does not make any such argument, we can find no reason to alter our views.

Mitchell also claims that we are guilty of "inappropriate comparisons," particularly in our account of communism, which we based on contemporary theoretical works from, as well as observed practice in, Soviet-bloc countries. For neither liberalism nor communism do we rely on the original classics, neither Locke nor Marx, as Mitchell appears to wish us to. An ideal type of communist regime derived from Marx, rather than from Lenin or via Soviet practice, either is likely to look very much like our social democratic liberalism, or will have few or no empirical referents. We should also note that while Mitchell may find it unsurprising that communism à la the Soviet Union falls short of international human-rights standards, such a view is very controversial, as several works cited in our article indicate. Furthermore, we want to stress that Soviet human-rights shortcomings do not arise merely because that country has deviated from the "true" path of socialism. Theoretical concepts such as the dictatorship of the proletariat demand denial of human rights.

Mitchell finds particularly "curious" our argument that economic benefits in communist regimes are not enjoyed as human rights. He appears to believe that having the substance of a right, for example, having access to health care, is synonymous with having a claim against the state to provide it. We agree that having the substance is better than nothing at all, but it is a privilege (subject to arbitrary state removal without any kind of redress, even in principle or law) rather than a right. In communist regimes, all rights are contingent grants of the state, rather than entitlements one has simply as a human being. This difference, enshrined in practice and even in the Soviet constitution, is of monumental theoretical and empirical importance. Mitchell claims however that Article 29 of the universal declaration supports the Soviet constitution by stating that the enjoyment of human rights is contingent on the discharge of social duties. It does not; rather it holds that "everyone has duties to the community in which alone the free and full development of his personality is possible," and that the only legitimate reason to limit an individual's rights and freedoms is to secure "due recognition and respect for the rights and freedoms of 


\section{American Political Science Review Vol. 81}

others." While in the Soviet constitution rights are contingent on the fulfillment of duties, no such contingency is provided in the universal declaration.

There are also three minor points to which we would like to respond. First, Mitchell takes issue with our description of minimalism as internally inconsistent. We readily agree that a political regime can quite comfortably adhere to an inconsistent set of political principles. But we do believe that a fundamental internal inconsistency (and one that reflects a clear class bias) is enough to remove minimalism from consideration as a plausible regime for those concerned with human rights.

Secondly, he claims that we do not clearly specify the origin of liberalism. But we did state as briefly as we could the generally accepted proposition (with which we expect he would agree) that liberalism arose with the creation of modern capitalist society, especially with the rise of the bourgeois class (p. 804). We agree that we did not explain, in this particular short article, why liberal regimes still violate so many rights.

Thirdly, Mitchell claims that our article is "remarkably barren in terms of producing empirical expectations about the variations of human-rights violations cross-nationally," and he states that we "presumably" believe that all nonliberal regimes perform "more or less equally badly." This is simply wrong. In the last half of our article, we explicitly differentiate among various nonliberal regimes. We do, in fact, provide some empirical expectations about human-rights performances. We think that traditional, communist, and perhaps developmental, regimes are more likely to provide for the substance of social and economic rights than minimalist or corporatist ones; and we also think that communist and developmentalist regimes are more likely to value equality than minimalist, traditional, or corporatist societies. From a moral point of view, we think equality is better than hierarchy, and the substance of social and economic rights is better than nothing at all, even if the regime holding these ideals is not rights based. Thus were we, for example, to be advising a U.S. president on foreign policy in Central America, we would advise supporting Nicaragua over Guatemala or El Salvador, in contrast, for example, to Jeane Kirkpatrick's (1979) minimalist preferences.

Finally, there is the charge of ethnocentrism, which Mitchell puts in a rather condescending fashion. As it comes out of the blue without any explanation, we can only ask, What is ethnocentric about taking a standard that is reflected legally in a universal document to which practically all states now pay at least lip service and that applies to everybody in an entirely universalistic fashion? Certainly, Mitchell does not appear to want to argue that any of the regimes we criticize respects human rights. Nor do we imagine that he wants to argue that simply because someone lives in a Third World Nation his or her government should be held to lower standards.

To insist on the universal relevance of international human-rights standards is not ethnocentrism. Rather, it is to insist on the liberating power, in a world of state societies, of the idea of human rights. And it is to refuse to agree that anything goes, that whatever a dictator or ruling class (of whatever ideological stripe) calls respect for human rights is such respect. Like so many others, Mitchell, out of a misplaced fear of ethnocentrism, would leave us unable to charge tyrants, despots, and oppressive ruling classes with violating human rights. A central objective of our article was to help lay to rest this all-too-familiar erosion of the idea of human rights.

RHODA E. HOWARD

McMaster University

JACK DONNELLY

University of North Carolina, Chapel Hill 


\section{Liberalism and Human Rights}

\section{Notes}

Neil Mitchell thanks James McCormick of Iowa State University and Karen Remmer of the University of New Mexico for their comments.

1. For Justice Thurgood Marshall, liberal documents and regimes seem to provide scant protection from repression. He said in 1978, "During most of the past two hundred years, the Constitution as interpreted by this court did not prohibit the most ingenious and pervasive forms of discrimination against the Negro" (McCluskey, 1986).

\section{References}

Berlin, Sir Isaiah. 1970. Four Essays on Liberty. Oxford: Oxford University Press.
Goldstein, Robert Justin. N.d. The United States of America. In An International Handbook of Human Rights, eds. Jack Donnelly and Rhoda E. Howard. Westport, CT: Greenwood.

Howard, Rhoda E. and Jack Donnelly. 1986. Human Dignity, Human Rights and Political Regimes. American Political Science Review 80: 801-17.

Kirkpatrick, Jeane J. 1979. Dictatorships and Double Standards. Commentary November, 34-45.

McCluskey, John. 1986. Law, Justice, and Democracy. 1986 Reith Lectures. The Listener, December 4, p. 16.

Skalnes, Tor, and Jan Egelund, eds. 1986. Human Rights in Developing Countries 1986. Oslo: Norwegian University Press. 